\title{
EDUCATING THE BLIND IN THE AGE OF ENLIGHTENMENT. GROWING POINTS OF A SOCIAL SERVICE
}

\author{
by \\ ROBERT HELLER*
}

Proxime mortis calamitas est caecum esse

Cardanus

CARDANus said, when discussing possible advantages to be derived from adversity, that next to death, blindness was the worst misfortune that could befall any person. ${ }^{1}$ This he wrote at the time of the Renaissance, but even when the age of Enlightenment had arrived, a blind person's position in society had not changed. Throughout the centuries we hear of isolated instances where blind persons in particularly privileged situations could attain achievements in some intellectual pursuits like, for instance, Elizabeth Waldkirch in Switzerland in the late seventeenth century. ${ }^{2}$ The vast majority of the blind, however, were rejected by society, and especially those who were blind from birth or early childhood, had no chance whatever of any form of education, nor of any employment. They could only expect a miserable life as beggars on street corners and at church doors or as mendicant street musicians. Blacklock ${ }^{3}$ looked on the neglect of the education of the blind as a social crime, which would rebound on to the society which had committed it. ${ }^{4}$ The first step towards progress in the education of blind people was made by the invention of an ingeniously simple appliance which enabled blind persons to perform mathematical calculations. This apparatus was invented by the blind professor of mathematics at Cambridge,

*Robert Heller, M.D., Wellcome Institute for the History of Medicine, 183 Euston Road, London NW1 2BP.

This article is based on a paper read at a meeting of the Society for the Social History of Medicine, London, on 13 October 1978.

${ }^{1}$ Hieronymus Cardanus, De utilitate ex adversis caspienda libri IV, Farneke, I, Balck, 1648, pp. 219-225.

'Elizabeth Waldkirch of Geneva was visited in 1686 by Gilbert Burnet, Bishop of Salisbury, who formed a very high opinion of her accomplishments. He reported that Mistress Walkier [sic] could speak four languages, played a number of musical instruments, could write legibly, and had an outstanding memory. See Gilbert Burnet, Some letters containing an account of what seemed most remarkable in Switzerland, Italy, etc. ..., Amsterdam, 1687, pp. 116-117.

s Thomas Blacklock (1721-1791). Blind Scottish clergyman and poet. Author of articles on blindness, as well as of several volumes of poems. See James Wilson, Biography of the blind, 3rd ed., Birmingham, Showell, 1835; and Rev. Mr. Spence, An account of the life, character, and poems of Mr. Blacklock, London, R. \& J. Doddsley, 1754.

'Article under the heading 'Blind', in Encyclopaedia Britannica, 2nd ed., Edinburgh, Balfour, 1778, vol. 2, pp. 1188-1204. 


\section{Educating the blind in the age of enlightenment}

Nicholas Saunderson. ${ }^{5}$ Saunderson showed no inclination to explain the nature of his aid to calculations to anyone. Neither had he published anything during his lifetime. After his death his widow had to ask one of Saunderson's colleagues to find out the working of her late husband's apparatus, which she had found among his books and papers. In the year following his death his widow and his son published Saunderson's work on algebra, to which there is prefixed a biography of him as well as an explanation of his Palpable arithmetic. ${ }^{6}$ This appliance consisted simply of a small wooden board, subdivided into a number of small squares by thin strips of wood nailed on it. Each square had a central hole as well as holes around the periphery. Into these holes pins with large as well as smaller heads could be fitted. By varying the size and position of the pins within the squares all values from zero to nine could be expressed (see Fig. 1). In addition geometrical figures could be constructed by stretching silken threads between pins. Saunderson's arithmetic frame has been modified and adapted many times. It is still being used today in a modern form, made of plastic instead of wood and instead of cumbersome pins plastic dice with Braille characters are used. The very first modification of it occurred not long after its invention. It was re-invented in a much handier form by Henry Moyes. ${ }^{7}$ Moyes had not heard of Saunderson's invention. He described his own in a letter to the editor of the third edition of the Encyclopaedia Britannica. Like Saunderson, Moyes had developed his appliance only for his own personal use, without any intention to publish an account of it for the benefit of his fellow-sufferers. He wrote its description in the Encylcopaedia Britannica only after having been invited to do so.

In 1749 Denis Diderot published his Essay on blindness. ${ }^{8,9,10}$ Diderot does not seem to have been particularly interested in the blind as persons. The main object of his work was to raise and discuss a series of metaphysical questions, which he handled with great skill. He was particularly interested in the blind people who had been deprived of one major sense of perception. He also discussed the possible reaction of a person, blind since birth, who had his sight restored and was able to see objects for the first time in his life. Here he was able to draw on an example from real life. William Cheselden had published a report on the reactions of a boy of approximately fourteen years of age whose sight had been restored by a cataract operation. ${ }^{11}$ For a

- Nicholas Saunderson or Sanderson (1682-1739). Became blind at the age of one year on account of smallpox. Was elected Lucasian professor of mathematics at Cambridge in 1711.

- Nicholas Saunderson, The elements of algebra in ten books, Cambridge University Press, 1740, see vol. 1, 'Saunderson's palpable arithmetic decypher'd' pp. xx-xxv.

${ }^{7}$ Henry Moyes (1750-1807). Became blind at the age of three years through smallpox. Lecturer of chemistry at Edinburgh. Travelled in North America and settled finally in Manchester. See Wilson, op. cit., note 3 above, pp. 172-179; H. Moyes, letter in Encyclopaedia Britannica, 3rd ed., Edinburgh, Balfour, 1788-97, vol. 3, pp. 296-297.

- Denis Diderot, Lettre sur les aveugles à l'usage de ceux qui voient, London, 1749.

- English translation of the above: Denis Diderot, An essay on blindness, in a letter to a person of distinction, London, R. Dymott, 1773.

${ }^{10}$ Towards the end of his life Diderot wrote an addition to his essay, describing the case of a blind lady of the French aristocracy, Melanie de Salignac. See A. Wilson, Diderot, New York, Oxford University Press, 1972, p. 702.

11 William Cheselden, 'An account of some observations made by a young gentleman who was born blind or lost his sight so early so that he had no remembrance of ever having seen and was couched between thirteen and fourteen years of age', in: The anatomy of the human body, 4th ed., London, W. Bowyer, 1730, pp. 348-352. 


\section{Robert Heller}

considerable time after the operation the boy was unable to recognize distances, shapes, or proportions. Diderot was greatly impressed by Saunderson's achievements and devotes much space in his book to Saunderson and to a detailed description of his arithmetic frame. He could not, however, resist the temptation of inventing a completely fictitious conversation between Saunderson on his deathbed and a clergyman.

Diderot depicted Saunderson as an atheist saying to the clergyman words like: "If you want me to believe in God first you have to let me touch him!"12 As Diderot had come into conflict with the authorities, the entry under the heading "aveugle" in the Encyclopédie based on Diderot's essay, appeared with all the offending passages removed. ${ }^{13}$ The memory of innocent Saunderson having been cast by Diderot in the role of a rabid atheist seems to have lingered on in France rather a long time. As late as 1817 a French author, writing on the mentality of the blind, found it necessary to defend the blind in general against the accusation of them being atheists. ${ }^{14}$

In Diderot's book there is an illustration ${ }^{15}$ depicting a blindfolded man waving two sticks in the air in front of him. It is stated on that plate that it had been taken from Descartes' Dioptrique (see Fig. 2). The man seen on this picture was not meant to be a real person, but only an imaginary man to explain Descartes' theory of vision. He explains the act of seeing by the "invisible particles" encountering some kind of resistance when impinging on an object "like the blind man's stick". ${ }^{16}$ The artist who produced the illustration obviously drew the imaginary man using two sticks as he would otherwise use both his eyes. In reality, a person deprived of sight, using one or two sticks in the fashion as seen on the illustration would soon have some unpleasant experience, as he could not detect in this way any obstacles at ground level. Diderot, however, fell into this trap by taking the likeness of the imaginary man for that of a real one. He writes about his visit to a blind man in Puisaux, who went about with the aid of two sticks, who taught his children to read using raised letters, and who thought himself to be vastly superior to any seeing person. When asked what he most urgently desired he replied; "Longer arms"! It is probably quite justified to regard Diderot's blind man of Puisaux as a product of his imagination. Diderot may not have greatly furthered the cause of the education of the blind apart from popularizing Saunderson's invention, but he created a great deal of interest regarding blindness, throughout Europe.

12 Diderot, op. cit., note 9 above, pp. 56-65. The opinions which he had put into Saunderson's mouth, together with others expressed in his book, like those on the non-existence of innate notions of morality, earned Diderot a term of imprisonment. It took his influential friends three months to get him released from Vincennes prison. It had been feared that his prolonged absence as joint editor would jeopardize the publication of the great Encyclopédie. See Wilson, op. cit., note 10 above, pp. 103-116.

13 D. Diderot and J. Le Rond de Alembert, Encyclopédie etc. .., Paris, Briasson, 1762-72, vol. 3, pp. 34-41.

i4 Sebastién Guillié, Essai sur l'instruction des aveugles, Paris, [imprimé par les aveugles], 1817, pp. 51-59.

15 Diderot, op. cit., note 9 above, Fig. 1, facing p. 19.

16 René Descartes, La dioptrique, Leyden, Jean Maire, 1673, text used here: Charles Adam and Paul Tannery (editors), Oevres de Descartes, Paris, J. Vrin, 1973, vol. 6, pp. 81-228, see p. 84. 


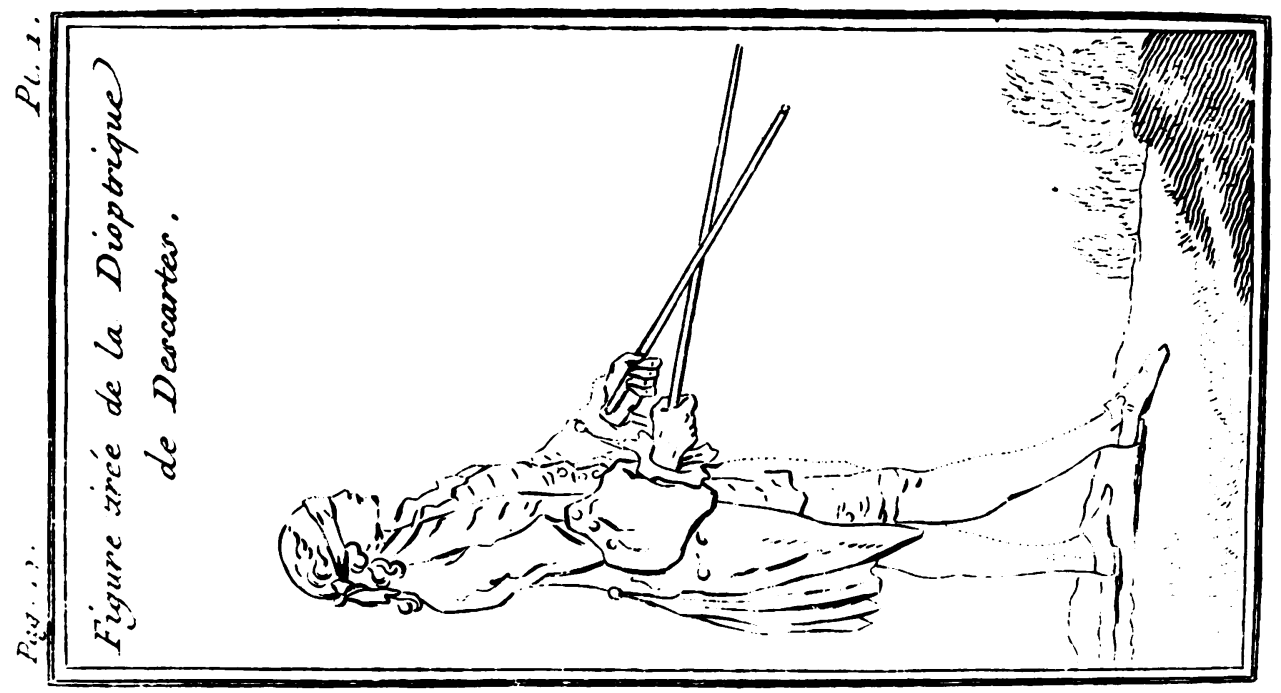

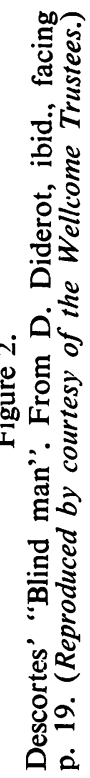

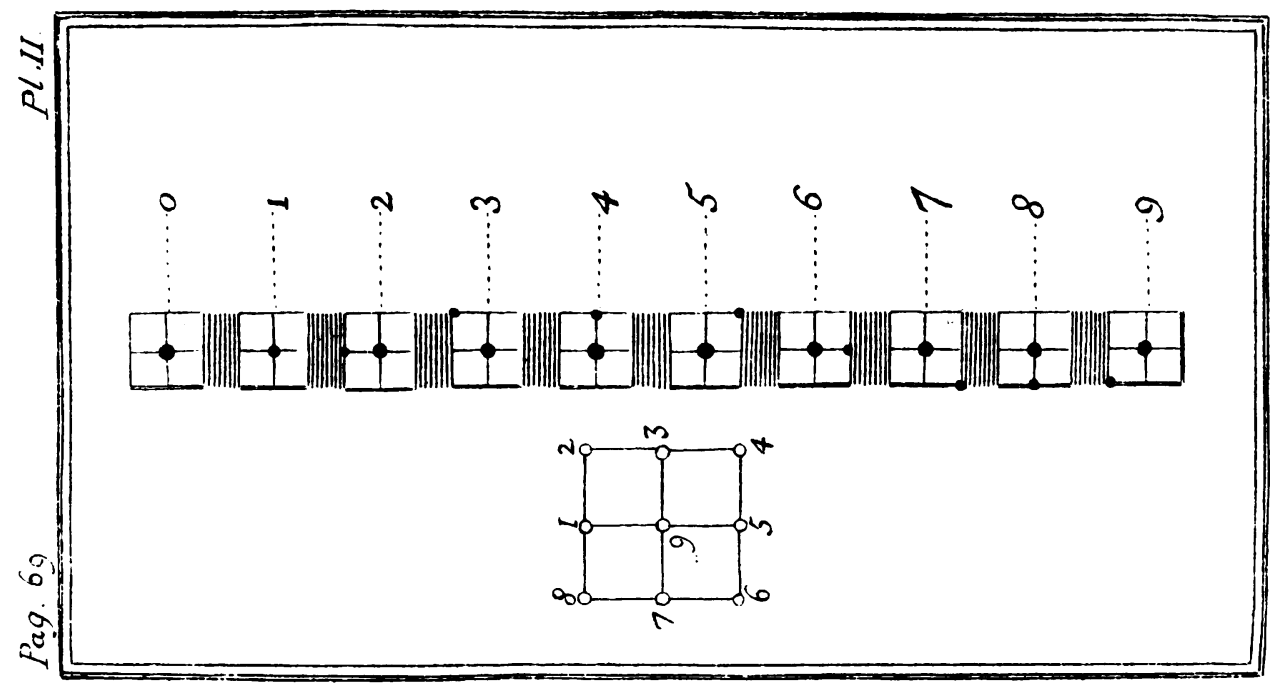

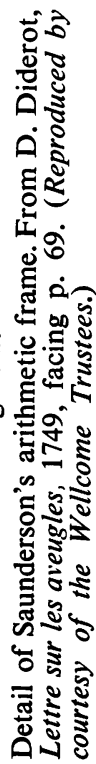




\section{Educating the blind in the age of enlightenment}

In the last quarter of the eighteenth century new methods for the education of the blind were being developed in Germany and Austria. The most prominent personalities in this field were undoubtedly Christian Niesen (1733-1784) and his pupil. A teacher of the "liberal arts", he was put in charge of the education of a highly intelligent young blind person, Johann Ludwig Weissenbourg (or Weissenburg) (1752-1800). Niesen became intensely interested in all aspects of the education of the blind. He was, however, a most retiring person and remains until today a somewhat shadowy figure. He published, however, two books on teaching arithmetic ${ }^{17}$ and algebra respectively. ${ }^{18} \mathrm{He}$ taught his pupil mathematics with the help of a modified version of Saunderson's frame. Weissenbourg learnt the alphabet on letters bent from thin wire. Niesen made "palpable" maps for him by embroidering the boundaries in silk on thin cardboard, while rivers were represented by thin wire shapes, glued on to the cardboard base. Pins with heads of different sizes represented towns of greater or lesser importance. Weissenbourg learned to play chess very well indeed on an only slightly modified chess set. He also played cards and astonished those onlookers who did not realise that he used playing cards which had been marked by pin-pricks in the margin. After his personal connexion with Niesen had ceased, Weissenbourg continued to acquire new skills. He taught himself to write on a writing frame, but had great difficulty writing with pen and ink. Pencils were also found unsuitable. Eventually he wrote with a stylus on blank paper, using a type of carbon paper to produce a legible script underneath. ${ }^{19}$ Weissenbourg kept up a correspondence, but mostly by letters dictated to an amanuensis, with another blind person Maria Theresa von Paradis. ${ }^{20}$ One of Maria Theresa's letters in reply to Weissenbourg's questions about her accomplishments summarizes them as follows:21 Apart from German, her mother tongue, she spoke a little French, could understand Italian, but could not speak it. She had some knowledge of geography, using Weissenbourg's method. She describes how she used her hand printing set, setting the type of each page herself and has it then checked. She was able to do the whole printing process herself, but preferred the printing to be done by somebody else, as the ink stained her fingers. ${ }^{22}$ She learned her music by heart. She had two pianos. A tune was

${ }^{17}$ Christian Niesen, Rechenkunst für Sehende und Blinde, Mannheim, Hof- \& Academische Buchdruckerei, 1773. Quoted in, Ottokar Warecek, Geschichte der Blindenpädagogik, Berlin, 1969, pp. 26-27.

${ }^{18}$ Christian Niesen, Algebra für Sehende und Blinde, Mannheim, C. S. F. Schwan, 1777. Quoted in Alfred Kistner, 'Christian Niesen, der erste Blindenlehrer und sein Schüler Johann Ludwig Weissenburg', Mannheimer Geschichtsblätter, 1921, 174-209, see p. 177.

$10 \mathrm{~J}$. L. Weissenbourg, letter to Niesen, dated 2 February 1791, in Rheinische Beiträge zur Gelehrsamkeit, 1781, pp. 69-72.

${ }^{20}$ Maria Theresa von Paradis (1750-1824). Celebrated blind Austrian concert singer and pianist. She had lost her sight at the age of three years. She was one of the victims of Franz Mesmer's fraudulent claims to be able to restore sight. Her sad case started the scandal during which Mesmer was exposed as an imposter by a committee of eminent Austrian physicians and surgeons. He was subsequently forced to leave Vienna. See Rudolf Tischer, Franz Anton Mesmer, Munich, Verlag der Münchner Drucke, 1928, pp. 52-58.

${ }^{21}$ M. T. von Paradis, letter to Weissenbourg, dated Vienna, 8 April 1780, in Rheinische Beiträge zur Gelehrsamkeit, 1781, pp. 243-247.

23 Miss Paradis had been given a hand-printing set, designed and made by the Austrian inventor Wolfgang Ritter von Kempelen (1734-1804). He became known throughout Europe for his invention of the "mechanical chess player", which he demonstrated with great acclaim in the presence of most 


\section{Robert Heller}

played to her, which she then immediately repeated on the other instrument. In this way she could learn a piece of music within one or one and a half lessons without difficulty. In 1884 Miss Paradis set out on a concert tour of Germany and in the following year she performed in Paris with great success. She also met there the founder of the first school for the blind, Valentin Haüy, and they had occasion to compare notes on aids for the education of the blind. Six months later Maria Theresa repeated her artistic triumphs in London. As much as the efforts of Niesen, Weissenbourg, and Paradis were aimed at perfecting the tools of blind education, they remained chiefly designed for the use of a few persons, with the exception of Niesen's two publications. When a government official ${ }^{23}$ asked Weissenbourg whether he would allow his own methods to be published for the benefit of his fellow-sufferers, he refused. However, he acceded to the request that suitable parts of his correspondence should be published in the Rheinische Beiträge zur Gelehrsamkeit. ${ }^{24}$ Only very few letters that were lent to Kling were actually published. ${ }^{25}$

In the year 1774 we find in a short-lived Edinburgh journal ${ }^{26}$ a letter on the education of the blind. It was signed with the pseudonym "Demodocus". ${ }^{27}$ It had actually been written by the blind Scottish clergyman and poet Thomas Blacklock. ${ }^{28}$ This article gives, perhaps for the first time, a very sensitive account of the feelings and the emotional needs of a blind child and offers good advice on some aspects of bringing up blind children. This perfect understanding of a blind young person's emotions is, of course, easily explained by the fact that Blacklock himself was blind since his very early childhood. This fact, however, Blacklock was at great pains to conceal in his poems as well as in his other writings. The editor of the Encyclopaedia Britannica found it necessary to point out to his readers that the author of Blacklock's contribution to that work (although writing as if he were sighted) was in fact blind. ${ }^{29}$ In the article under the heading 'Blind' in the second edition of the Encyclopaedia Britannica published four years later, the text of the letter 'On the education of the blind' (reprinted verbatim) forms an integral part of the article under the heading 'Blind'. ${ }^{30}$ In the third edition of the Encyclopaedia Britannica Blacklock's article appears again,

of the members of the royal families of Europe. It was a life-size wooden figure of a Turk. The chessplaying ability of this figure was said to be stupendous. In the end Kempelen revealed his secret: within the apparatus a dwarf had been concealed to operate the mechanism. See Marlene Jantsch, 'Das Leben der Maria Theresia Paradis und seine Bedeutung für die Blindenbildung', Wien. med. Wschr., 1955, 105: 973-982.

23 Johann Peter Kling (1749-1809). High-ranking official at the Court at Mannheim, later at Munich. Scientist and writer.

s4 J. P. Kling, letter to Weissenbourg and his reply, in Rheinische Beiträge zur Gelehrsamkeit, 1781, 1: $234-242$.

${ }^{25}$ Kistner, op. cit., note 18 above, p. 202 . He believes that only a few letters were found to be worth publishing by Kling.

20 'On the education of the blind', letter dated 10 September 1774, in Edinburgh Magazine and Review, 1774, 2: 673-686.

${ }^{27}$ Demodocus, the minstrel of Alcinous, blind, but very gifted. Oxford classical dictionary, London, Oxford University Press, 1970, p. 329.

${ }^{28}$ See note 3 above.

20 Th. Blacklock, 'Blind', in Encyclopaedia Britannica, 3rd ed., Edinburgh, Balfour, 1788-97, vol. 3, pp. 283-306, see footnote F on p. 293.

${ }^{30}$ See note 11 above. 


\section{Educating the blind in the age of enlightenment}

further enlarged and dealing with all aspects of blindness, taking into account all new developments concerning the welfare of the blind. This also includes a précis of a translation of Valentin Haüy's book on his newly founded school for blind children in Paris.

Blacklock's article can probably be considered as the most important work in Britain on the subject of blindness at the time, especially as it reviews all recent advances concerning the welfare of the blind. For this reason a closer look at its contents seems to be well worth while.

At the onset the author states that he did not intend to treat his subject from the medical nor from the metaphysical point of view. His main aim was to discuss the disadvantages of blindness as well as any advantages that might be gained, but principally all the ways and means by which this dreadful condition could be alleviated. He first describes in great detail, obviously from personal experience, the great handicap that blindness means for the afflicted persons and how their spirits are affected accordingly. He then quotes passages from Homer, Milton, and Ossian expressing the tragic fate of the blind. The blind, however, derive some advantages from their condition, not enough to compensate them for, but at least to alleviate their fate. The contemplations of the soul are less distracted by the constantly changing impressions received through the sight. Some senses, like touch and hearing, take over to some extent. He, however, dismisses the statements, at that time often discussed, that the blind could distinguish colours by touch. Blacklock states that the blind persons were not only capable of great intellectual achievements, but could also become very skilful with their hands. Blacklock then considers the results of tests and experiments carried out to investigate the nature of vision, but doubts whether they have been conducted properly. He refers the readers to Cheselden's Anatomy, ${ }^{30}$ to Diderot's Letter on the blind ${ }^{31}$ and Locke's Essay on the human understanding. He is very doubtful of some exaggerated reports of extraordinary powers of blind persons, but states that it had been proven that they were capable of concepts of light and colour. Blacklock then refers to the use of adjectives denoting colours by the blind, especially by blind poets. He explains this by remarking that poets who become blind in later life could probably still remember the colours. Poets who had been blind since early childhood would use these adjectives to describe certain features parrot-fashion, as they have heard them described, like blue sky, red roses, white lilies, etc. Blacklock then uses the opportunity to quote a highly flattering opinion of a foreign author on his own linguistic accomplishments as well as on his poetry. ${ }^{32}$ He then enters on the subject of the education of the blind. He begins by stating that it was impossible to give detailed advice as a great deal depended on the individual circumstances, the personality of the blind person, etc. He could only give some general rules, which had then to be applied according to the individual case. Blacklock condemns the complete neglect of the education of the blind, which he expresses in the following words: "Nor do the blind bear so small a proportion to the whole community, as, even in a political view, to be neglected. But in this, as in every other political crime, the punishment returns upon the society in which it is committed.

${ }^{31}$ See note 8 above.

82 Blacklock, op. cit., note 29 above, p. 288. 


\section{Robert Heller}

Those abandoned and unimproved beings, who under the influence of proper culture and discipline might have successfully concurred in producing and augmenting the general welfare, become the nuisances and burdens of those very societies who have neglected them." ${ }^{33}$ Civil and ecclesiastical employment was almost entirely inaccessible for the blind either on account of inherent difficulties or of invincible prejudice. ${ }^{34}$ Blacklock can see no reason why the blind should not become efficient clergymen. Medicine was not possible as a profession suitable for the blind. Music was probably the best sphere in which to be able to make a living. The public expected some educated blind persons to be in possession of extraordinary powers and they were looked upon as "rareshows". If they did not come up to expectation they were despised. Blacklock advises parents and tutors not to restrict the movements of their blind charges, to let them walk about in the neighbourhood without guide even at the risk of an injury. He also asks them not to forbid a boy with a mechanical bent to use tools with a sharp edge. Blind children should be made to be independent as soon as possible, but to begin with it was advisable that they should be discretely supervised from a distance. Exercise suitable for blind children is then described. Horseriding takes first place. Failing this, apparatus stimulating the action of a horse is suggested, as well as exercises with dumb-bells. An indoor swing is also considered beneficial. Then follows advice on food and drink. Tobacco and tea are strictly forbidden. A considerable amount of space is given to the prevention and cure of taedium vitae or low spirits. Parents and tutors are warned to look out for the symptoms of this disease. Once it has taken hold of the young patient, cold baths, vitriolic acid, or Peruvian bark will be the most effective remedies. Magnesia alba will sometimes help or tincture of valerian. The patient should be pleasantly distracted and amused. There is a great deal of very sound advice on managing the young patients along psychological lines.

Parents "of middle or higher rank" are advised to keep their childen out of vulgar company. Children can be greatly hurt by heartless derision on account of their condition. A very sensitive piece of advice is given by the author about telling blind children horrific stories of ghosts, evil spirits, and similar horrors of the dark. One can well imagine that the author himself had greatly suffered from ghostly tales, told to him by well-meaning, but thoughtless people. Blacklock then quotes some achievements of blind persons. He provides a detailed description of Saunderson's arithmetic frame, translated from Diderot's Essay on the blind. ${ }^{35} \mathrm{He}$ then reprints a letter to the editor from Henry Moyes with a description of Moyes' improvement of Saunderson's apparatus. ${ }^{36}$ For drawing geometrical figures, the author proposes to use a large table, covered with beeswax, on which lines could be easily drawn, felt with the fingertips, and also easily deleted. ${ }^{37}$

23 Ibid., p. 288. In today's parlance, Blacklock would have used the term "social crime".

s4 Blacklock speaks from personal experience. Licensed as a preacher in 1759, he was presented by the Crown to the ministry of Kirkcudbright. The parishioners, however, did not accept him on account of his blindness. After a legal wrangle lasting for two years Blacklock had to retire on a meagre pension. See Wilson, op. cit., note 3 above, pp. 28-48.

ss Blacklock, op. cit., note 29 above, pp. 295-296.

28 Ibid., pp. 296-297.

27 Ibid., p. 297. 


\section{Educating the blind in the age of enlightenment}

Blacklock continues and says that what he had written so far on the subject was now superseded by the publication of a book in Paris, which he describes as follows: "... but a book has been lately published at Paris which supersedes every former attempt to promote or facilitate the improvement of the blind. The invention of a plan so arduous in its appearance and so practicable in its execution, demanded the highest exertion of the noblest genius to produce it, and the most strenuous efforts of indefatigable humanity to render it effectual. It is intitled, An Essay on the Education of the Blind." 38 A whole page of the Encyclopaedia is devoted to the description of the contents of this justly famous book. Blacklock continues with the review of subjects he thought suitable for teaching to the blind. He mentions astronomy and thinks that an orrery would be indispensible for teaching this subject. Moral and theological knowledge should be quite easy to impart. Religion was particularly important for the blind. He also recognizes the great value of what he terms self-determined enjoyment. Blacklock thinks that philosophical learning was easy enough to obtain, but tedious. Languages, however, were most useful. Logic, history, and belles-lettres were equally very useful subjects.

The relatives of young blind people, if in easy circumstances, should provide a suitable companion of roughly the same age and of pleasant temperament. If, however, the blind pupil would have to rely on his own efforts to earn his living, music, as the author had already mentioned, was the obvious choice. Blacklock, however, gives a warning in these passages: "let it at the same time be remembered that mediocrity in this art may prove the bitterest and most effectual curse which a parent can inflict upon his offspring as it subjects them to every vicious impression or habit which may be imbibed or contracted from the lowest and most abandoned of mankind. If your pupil, therefore, be not endowed with natural talent, exquisitely proper. both for the theory and practice of this art, suffer him by no means to be initiated in it." ${ }^{39}$ Spinet, harp, or organ were the instruments of the author's choice. Blacklock follows this with a long, minute description of a system of musical notation for the blind, consisting of a board with many holes and several different types of pegs. ${ }^{40}$ This description is followed by an account of Mr. Cheese's method of notation. This consists of a small long cushion, on which the lines are represented by an equal number of pack-thread sewn on it. The notes are represented by several differently headed pins. Blacklock concludes his review with an impassioned plea for society to give the blind a better place in the community by according them better education. He writes: "It now remains to demand a categorical answer from society. Whether it is more human and eligible, that such unhappy persons should be suffered to languish out their lives in torpid and miserable obscurity wretched in themselves and burdensome to others, or to cultivate and improve their powers in such a manner as that they may be qualified for internal enjoyment and public utility?"41 Nowhere in his writings on the subject of blindness did Blacklock make any concrete suggestions of creating schools for blind children, whose parents could not afford to

9. Valentin Haüy, Essai sur l'education des aveugles, Paris, [imprimé par les enfants aveugles], 1786.

20 Blacklock, op. cit., note 29 above, p. 300.

¿ Ibid., pp. 300-301.

41 Ibid., p. 303. 


\section{Robert Heller}

have them educated privately. The nearest he seems to have got to suggest this course is a passage in his rather turgid prose, contained in the penultimate sense, as follows: "You men of wealth and eminence, ... yours is the glorious province of bringing neglected merit from obscurity, ... and of cultivating those talents which may be exerted for your own advantage and the honour of your species." 42

The first decisive step to set up a school for poor blind children, designed to enable them to lead a useful life in the community, fit to earn their living, without having to rely on charity, was undertaken in France by Valetin Haüy..$^{43} \mathrm{He}$ was a government translator and interpreter and an expert on ancient manuscripts. He tells in his book how he became interested in the education of the blind initially and what moved him to devote his energy for the rest of his life to this cause.44 One evening, while strolling along a Paris boulevard, he noticed a group of blind people in clowns' clothing on a raised platform in front of a café, who made some awful noises on musical instruments, pretending to play them. On their noses they wore large cardboard spectacles. The passers-by thought this performance very funny, but Haüy was greatly shocked by it. This incident, according to Haüy, determined him to devote himself to the education of the blind. ${ }^{45}$ Before, however, he could persuade the public to contribute to a problematic and possibly costly venture such as creating a school for blind children, he had to prove that such an undertaking was feasible. He therefore conducted an experiment by literally lifting a young blind beggar out of the gutter and teaching him the rudiments of primary education. ${ }^{46}$ The result of this experiment was most encouraging and soon it was possible for Haüy to show his pupil in influential circles. A small committee of the Académie Royale des Sciences was formed, and the boy was examined by it. The committee's report was most favourable and the newly formed Philanthropic Society of Paris undertook to set up a small school for blind children with Haüy as its head. The syllabus of Haüy's school was most ambitious. The subjects taught are well documented in two books, Haüy's and his successors'. ${ }^{77}$ Haüy's book is an extraordinary document. It was printed by blind young people in his institution, for the use of blind and sighted readers alike, ${ }^{48}$ by using raised print, and also bound by blind children. It proclaimed Haüy's aims for a thorough academic education, was a true milestone in the history of the rehabilitation of the handicapped, and opened up a new dimension in the education of the blind. The education of sighted and blind pupils and of boys and girls side by side were quite novel procedures in Haüy's time. Great emphasis was put on the teaching of the elements of education, on reading, writing, and arithmetic. Raised

12 Ibid.

a Valentin Haüy (1745-1822) was the brother of René-Juste Haüy, the founder of crystallography. Valentin Haüy founded the first school for blind children in Paris. He was the head of this institution until he was dismissed in 1802, under Napoleon Bonaparte's regime.

" Haüy, op. cit., note 38 above, pp. 119-123.

es Ibid.

ce The name of the blind beggar boy used by Haüy in his educational experiment was François Lesueur. He became subsequently a teacher at Haüy's school, and later its treasurer.

12 Guillié, op. cit., note 14 above.

\&8 The first mention of raised letters for the use of the blind occurs in Francesco Lucas, Arte de escriver, Madrid, 1577, quoted by J. H. Wagg, Chronological survey of work for the blind, London, Pitman, 1932. 


\section{Educating the blind in the age of enlightenment}

letters were employed for enabling the blind to read. ${ }^{49}$ The printing of embossed letters was done by placing the type-face upwards on to the press, covering it with specially thick paper, which would hold the shape of the raised letters well pressed on it. The paper would be moistened and then pressed with some force against the type, either by means of the press or by hitting the paper with a wooden mallet. For the purpose of learning to read, the sighted pupils could use a primer which was written in ordinary black-on-white letters, while the blind pupils would use one printed with embossed letters.

The first steps in learning to write undertaken by the blind pupils consisted of acquainting themselves to form letters by tracing with a stylus letters engraved in a sheet of metal. ${ }^{50}$ The actual writing was done in ink with a pen on paper which was put into a writing frame, as described by the Italian Jesuit priest Lana-Terzi in $1670 .{ }^{51}$ A sheet of soft material could be placed under the paper in the writing frame, which produced an embossed effect on the underside of the writing paper, making it possible for the blind to "read" what they had written in mirror writing. Guille mentions, while describing the methods of writing for the blind, the efforts to produce an ink which would dry on the paper so that the writing would stand out in relief. ${ }^{52}$ These efforts were, however, not successful as the ink had the tendency to dry already on the pen.

Geography was taught with the aid of "palpable" maps, as originally introduced by Niesen.

For the teaching of mathematics a modification of Saunderson's frame was used. Instead of pins, raised normal numerals were employed; this was cumbersome but enabled blind and sighted children to be taught side by side.

The children learnt according to a system of mutual assistance. A young, sighted newcomer to the school would learn the letters of the alphabet from a blind pupil by means of raised letters, whereas the sighted pupils would act as readers to the blind ones and would, for example, look up words in the dictionaries.

The teaching of music was given great care and much thought. It was realized that music would play a big part in a blind person's life. ${ }^{53.54}$ Haüy established a choir and an orchestra of blind children, who gave public performances. The children were not taught to rely on a system of musical notation, but to rely on their auditory memory, i.e., they played or sang by ear. In the teaching of solo instruments it would be taken into consideration whether or not the pupil would be able to have access to a keyboard instrument when he returned to his native province. If the pupil was bound to return to a remote area with no access to a keyboard instrument, the

19 Haüy, op. cit., note 38 above, pp. 44-58.

so This method was suggested by Cardanus. See, H. Cardanus, De subtilitate libri XXI, Nürenberg, Joh. Perrius, 1550, liber decimus septimus, p. 331. The same method, however, was used by Quintillian to teach writing to sighted children. See, The institutio oratoria of Marcus Fabius Quintillian, Loeb Classical Library, London, Heinemann, 1931, vol. 1, pp. 32-35.

${ }^{51}$ Padre Francesco Lana-Terzi, Prodromio . . . . etc., Brescia, Rizzardi, 1670, pp. 37-43. See Vincenzo Busacchi, 'L'istructione dei ciechi, problema sociale ed i suoi precursori, lo spirito antiveggente di G. Cardano e Lana-Terzi', Riv. Stor. Med., 1975, pp. 3-19.

s Guillié, op. cit., note 14 above, p. 143.

$8 s$ Ibid., pp. 165-170.

sc Haüy, op. cit., note 38 above, pp. 84-91. 


\section{Robert Heller}

musical instruction concentrated rather on a wind instrument, like the serpent, A rule of Haüy's school was that each pupil had to learn a practical trade, so that he or she could maintain himself or herself even if there could be no scope to use the academic or musical education received at the school.

The Revolution was not a happy time for Haüy's institution. In 1791 it was taken over by the state, and the blind children were housed, together with deaf-mutes, in a huge, cavernous building which formerly had been the convent of the Celestine nuns. ${ }^{55}$ There they lived under considerable hardship. During this time a most interesting development took place. The blind and the deaf-mute children worked out a system of communication with each other without having been taught it. The deafmutes managed to teach the blind their finger language which the blind could then "read" with their own fingers. Guille gives a moving account of the children trying, not always successfully, to communicate with each other in almost complete silence during the recreation period at their school. ${ }^{56}$

The post-revolutionary period brought new hardship for the blind pupils. They were transferred in 1802 to the Hôpital des Quinze-vingts. This institution was in effect a workhouse for blind beggars, where the children received no instruction to fit them for a useful life in the midst of a normal community. Haüy was dismissed with a meagre pension. ${ }^{57}$

In Britain the first institution for the education of the blind was founded by public subscription in Liverpool in $1791 . .^{58}$ This institution was of a very modest nature and was not suitable for residential use. It consisted of two small private houses, and the pupils lived in their parents' homes or lodged in private houses in the vicinity of the school. ${ }^{59}$ In London a school for the blind was established in St. George's Fields in $1799,{ }^{60}$ and in 1803 similar schools were established in Bristol ${ }^{61}$ and in Edinburgh. ${ }^{62}$

From then on there follows the establishing of new schools for blind children in all larger centres of population throughout Europe, in North America, and the developed countries throughout the world. These events signified a movement for

\footnotetext{
sb A well-documented account of Haüy's institution during the Revolution and the post-revolutionary period is contained in, Dora Weiner, 'The blind man and the French Revolution', Bull. Hist. Med., 1974, 48: 60-89.

be Guillie, op. cit., note 14 above, pp. 170-174.

${ }^{57}$ After his dismissal Haüy tried unsuccessfully to establish a private school for blind children. On invitation of Tsar Alexander I he went to St. Petersburg to establish a school for blind children there. This turned out to be one of Tsar Alexander's unrealistic schemes. Haüy eventually returned to France, where he died in 1822.

s8 Edward Rushton, a colourful personality, former landlord of an inn, poet, and newspaper editor, managed to rouse local interest in Liverpool for the creation of a school for the blind by public subscription. He had personal experience of blindness. When serving as second mate on a ship carrying Negro slaves, a serious eye disease broke out among the slaves confined in the hold. Rushton insisted on going to the assistance of the afflicted victims, contracted the disease, and lost his sight. See Wilson, op. cit., note 3 above, pp. 136-153.

so An address in favour of the school for the blind in Liverpool, instituted in the year 1791, Liverpool, G. F. Harris, 1808.

${ }^{\infty}$ An account of the school for the indigent blind in St. George's Fields, Surrey, London, Philanthropic Society, 1813, pp. 5-7.

'1 Report of the Bristol Asylum and School of Industry for the blind, Bristol, 1801.

es W. Illingworth, History of the education of the blind, London, Sampson Low, 1910.
} 
Educating the blind in the age of enlightenment

rehabilitation of one class of disabled persons and a beginning of a social service the growing points of which can be already discerned in the eighteenth century.

\section{SUMMARY}

The beginnings in the eighteenth century of a social service and a movement to rehabilitate one particular kind of disabled person, the blind, are described. 